мови / Л. П. Рожило, О. М. Шпортенко // Українська мова і література в школі. 1973. - № 2. - C. 58-64.

\title{
ФОРМУВАННЯ КРИТИЧНОГО МИСЛЕННЯ УЧНІВ НА УРОКАХ РОСІЙСЬКОЇ МОВИ ТА ЛІТЕРАТУРИ ЯК ОСНОВА РОЗВИТКУ ІННОВАЦЙНОЇ ОСОБИСТОСТІ
}

Лисевич О. В., Медведєва Н. Г. Формування критичного мислення учнів на уроках російської мови та літератури як основа розвитку інноваційної особистості.

У статті розкрито прийоми й методи формування критичного мислення учнів, обгрунтовано їх уплив на розвиток інноваційної особистості. Доведено, що необхідними умовами для вияву критичного мислення учнів $є$ наявність творчих особистостей, творчого процесу, творчого середовища.

Ключові слова: критичне мислення, нові педагогічні технології, інноваційна особистість.

Лисевич А. В., Медведева Н. Г. Формирование критического мышления учеников на уроках русского языка и литературы как основа развития инновационной личности.

В статье раскрыты приёмы и методы формирования критического мышления учащихся, обосновано их влияние на развитие инновационной личности. Доказано, что необходимыми условиями для проявления критического мышления учеников является наличие творческих личностей, творческого процесса, творческой среды.

Ключевые слова: критическое мышление, новые педагогические технологии, инновационная личность.

Lisevich A. V., Medvedeva N. G. The formation of critical thinking at the lessons of the Russion language and literature as a basis for the development of innovate personality.

The article presents the techniques and methods of formation of critical thinking. It substantiates their influence on the development of innovate personality. The author also insists that the presence of critical thinking at the lessons, creative process, and creative environment are the important factors for the realization of the pedagogical creativity in the process of teaching.

Key words: critical thinking, new teaching technologies, innovate personality.

В умовах створення демократичної держави важливе значення має виховання людей, які мислять самостійно i творчо. Людей, які б мали змогу критично осмислювати факти і події довкілля, які б втілювали нові ідеї в усі галузі суспільства, були б вільними від конформізму й догматизму, оскільки незаперечним $\epsilon$ факт, що багато людей не здатні самостійно і критично оцінювати суперечності реального життя. Критичне мислення $\epsilon$ не тільки результатом демократичного способу життя, але й чинником його формування.

«Удосконалення загальної середньої освіти спрямоване на переорієнтацію навчання на розвиток особистості учня, навчання його самостійно оволодівати новими знаннями. Сучасна молода людина об'єктивно змушена бути більш 
мобільною, інформованою, критично i творчо мислячою, а отже, i більш мотивованою до самонавчання і саморозвитку» [2, с. 24 ].

Виходячи 3 цього, ми бачимо актуальність проблеми в тому, що перед сучасною школою постає завдання виховати людину незалежну, вільну, здатну самостійно осмислювати явища навколишньої дійсності, відстоювати свою власну думку перед будь-ким і будь-де.

Метою статmі є спроба виокремити основні підходи та шляхи формування критичного мислення учнів на уроках російської мови та літератури як основу розвитку інноваційної особистості.

У «Пояснювальній записці» Програми з російської мови наголошено на тому, що «навчання російській мові в середніх навчальних закладах сприяє формуванню гуманістичного світогляду, духовного світу особистості, iї моральних та естетичних цінностей; розширенню культурно-пізнавальних інтересів учнів, вихованню в них поваги до традицій свого народу, толерантного ставлення до культурних традицій інших народів; становленню громадянина України, що сприймає та позділяє національні та загальнолюдські цінності» [4; 5]. Отже, мета навчання російської мови - досягнення вільного володіння нею в усіх видах мовленнєвої діяльності на основі мовної, мовленнєвої, соціокультурної компетенції.

Програми зі світової літератури мають на меті «засвоєння школярами загальнолюдських духовних та художніх цінностей російської та світової літератури, виховання в них інтересу до читання та вивчення кращих зразків творів мистецтва слова; набуття учнями знань про розвиток російської літератури в контексті світового літературного процесу від стародавності до наших днів, збагачення та розширення їхнього читацького світогляду» [3, с. 19].

У сучасних умовах учитель повинен обирати 3 різноманіття методик ту оптимальну, реалізація якої сприяє досягненню мети - виробити в учнів вміння демонструвати набуті на уроках навички мовленнєвої поведінки, полеміки та критичного мислення, але при цьому не втратити інтересу до читання та вивчення кращих творів російської та світової літератури. Учень продовжуватиме вже сам, без допомоги педагогів, формувати вміння критично аналізувати та виявляти особистісне ставлення до того, що прочитав, тобто стане кваліфікованим читачем.

Проблема формування критичного мислення в учнів активно вивчається вітчизняними та іноземними педагогами вже понад десять років. Названа технологія - це педагогічна система, спрямована на формування в учнів аналітичного мислення. Засновниками цього напрямку були такі видатні науковці, як Л. Виготський, Джон Дьюі; М. Коул, Д. Верті, Д. Брунер. Свої наукові дослідження присвятили цій проблемі канадський професор Ральф Х. Джонсон, американський науковець Девід Клустер, вітчизняні науковці М. Красовицький, О. Бєлкіна, Ю. Стежко, педагоги-новатори Одещини С. Пеняєв, О. Боровська.

Їхні дослідження і практичне впровадження учителем прийомів розвитку критичного мислення в учнів на уроках доводять ефективність навчального процесу.

Виховати інноваційну особистість традиційними методами неможливо. Тільки інноваційне навчання здатне сформувати особистість, яка підготовлена до динамічних змін у соціумі за рахунок розвитку здібностей аналітично мислити, творчості, а також здатності до співпраці з іншими людьми.

Навчити учнів самостійно працювати 3 інформацією, формулювати оригінальні ідеї, розв'язувати проблеми й обговорювати їх у класному колективі неможливо без правильної організації навчання. 
Наприклад, на етапі «Розминка» у 5 класі перед початком вивчення теми «Синтаксис. Пунктуація» пропонуємо учням закінчити одним словом речення: «Уміти правильно будувати речення потрібно, щуоб...», «Уміти правильно ставити розділові знаки в реченні потрібно, тому...» Активізує розумову діяльність старшокласників таке завдання розминки: учитель пропонує учням слово, яке може бути назвою теми уроку, ключовим словом уроку чи поняттям, яке застосовується на уроці. 3 літер цього слова учні повинні утворити нові слова. Наприклад, на уроці російської мови у 10 класі учитель запропонував на розминку слово «пунктуація». Учні придумали такі слова: пункт, пункція, унція, акація та інші.

Удало використовується розминка «Кросворд», коли учням пропонується скласти простий кросворд тільки з горизонтально розташованих слів. По вертикалі вчитель пропонує слово, яке $є$ темою уроку чи його ключовим словом. Учні об'єднуються у групи, кожна 3 яких пропонує слово, у якому була б літера «ключового» слова, супроводжуючи його своїм коментарем. Слова мають відповідати предмету вивчення.

Наприклад, на уроці світової літератури у 5 класі під час вивчення літературної казки О. Пушкіна «Сказка о мертвой царевне и семи богатырях» можна запропонувати кросворд, ключове слово в якому - ПУШКИН. Учні пропонують вписати в нього слова, що допомагають охарактеризувати царівну.

Есе як метод формування критичного мислення полягає в написанні тексту в довільному стилі. Це дозволяє учням глибше зануритись у проблему й власний внутрішній світ під час її розв'язання, розвивати спостережливість, збагачувати свій словниковий запас, а також «почути» себе, виявити повагу як до своєї думки, так i до думок інших людей.

Асоціація спонукає до вільного й відкритого мислення. Цю стратегію рекомендовано використовувати як під час групової роботи, так i під час індивідуальної.

Такий прийом, наприклад, був використаний під час вивчення п'єси В. Шекспіра «Ромео і Джульєтта» (тема уроку «Любовь меняет человека»). Пропоную учням записати ключове слово «любов» та дібрати слова-асоціації. Зазвичай учні пишуть:

\section{Страдание любовь счастье \\ Окрыление испытание верность}

Ураховуючи слова асоціативного куща, працюємо над образами Ромео та Джульєтти, виявляємо, як саме змінила любов обох героїв, разом читаємо уривки 3 тексту на підтвердження думок.

Співвідносний із методом «Асоціативний кущ» інтерактивний метод «Мозковий штурм», який $\epsilon$ ефективним також і на уроках російської мови на етапі актуалізації опорних знань або на етапі рефлексії. Переваги цього методу полягають у тому, що очевидна простота, збір інформації та ідей за відносно короткий відрізок часу.

Сенкан допомагає підсумувати інформацію, сприйняту на уроці, визначити головні ідеї, думки. Наприклад, сенкан, який склали учні 6 класу в результаті аналізу образу Негору, героя роману Ж. Верна «П'ятнадцятирічний капітан»:

Убийца.

Подлый, коварный.

Убегает, мешает, преследует.

Испортил компас на шхуне «Пилигрим».

Португалец. 
Метод ПРЕС допомагає учням навчитися знаходити вагомі аргументи i формулювати свою думку щодо спірного питання; визначитися у своїх ідеях, а також формулювати їх у вигляді чіткої та логічної структури. Ця стратегія може бути використана на будь-якому етапі уроку.

Робота в парах є різновидом групової навчальної діяльності учнів, об'єднаних спільною метою. Вона сприяє позитивному ставленню учнів до навчання, розвиває вміння пристосовуватись до роботи в групах, готує підгрунтя для широкого й ефективного застосування інтерактивних технологій. За умов парної роботи всі діти у класі отримують можливість говорити, обмінюватись ідеями, спілкуватись, допомагати один одному, висловлюватись, критично мислити, переконувати.

Цей вид співробітництва сприяє тому, що учні не можуть ухилитись від виконання завдання. Важливим $є$ й те, що, наприклад, працюючи в парах, учні виконують швидко вправи, на які в інших умовах потрібно більше витратити часу. Групова форма роботи з використанням різних методів і прийомів сприяє розвитку навичок спілкування, вміння критично мислити, висловлюватись, переконувати і вести дискусію.

Наведені приклади завдань спрямовані на розвиток критичного мислення учнів, їх особистісний потенціал, але використання будь-яких технологій не має бути епізодичним. Критично мислити учень може в будь-якому віці, але навчитися мислити критично не можна протягом одного уроку. Для цього необхідне систематичне застосування прийомів і методів, які б навчали учнів мислити критично та вдосконалювали та розвивали ці вміння. Це надає змогу досягти такої атмосфери у класі, яка найкраще сприяє співробітництву, порозумінню й доброзичливості між учнями, реалізувати особистісно зорієнтоване навчання.

Стан досліджуваної проблеми формування критичного мислення учнів на уроках російської мови та літератури як основа розвитку інноваційної особистості вимагає подальших наукових пошуків: методика діагностування рівня критичного мислення учнів, показники і критерії його сформованості, розроблення моделі й технології його формування.

\section{Література}

1. Дичківська І. М. Інноваційні педагогічні технології / І. М. Дичківська. - К. : Академвидав, 2004. - 352 с. 2. Загальні критерії оцінювання навчальних досягнень учнів у системі загальної середньої освіти // Всесвітня література в середніх навчальних закладах України. - 2008. - № 8. - С. 24 -28. 3. Література: Програми для 5-12 класів загальноосвітніх навчальних закладів 3 російською мовою навчання // Російська словесність в школах України. - 2005. - № 3. - С. 19-21. 4. Російська мова: Програма для 5-12 класів загальноосвітніх навчальних закладів 3 російською мовою навчання / Н. Г. Озерова, Г. О. Михайловська, Л. В. Давидюк, В. І. Статівка, К. І. Бикова. - Чернівці: Видавничий дім «Букрек», 2005. - 64 с. 5. Сиротенко Г. О. Сучасний урок: інтерактивні технології / Г. О. Сиротенко. Харків : ВГ «Основа», 2003. - 92 с. 